\title{
The Influence of Cooperative Learning Model Type Team Assisted Individualized of Interactive Media Assistance to Students' Mathematical Communication Ability
}

\author{
Yarmasi $^{1, \mathrm{a}}$, Mutia Fonna ${ }^{1, \mathrm{~b}}$, Mursalin ${ }^{1, c^{*}}$ \\ ${ }^{1}$ Department of Mathematics Education, Malikussaleh University, Aceh Utara, Indonesia \\ a yarmasi488@gmail.com; b mutia.fonna@unimal.ac.id; c mursalin@unimal.ac.id \\ *Corresponding Author: mursalin@unimal.ac.id | Phone : +6285260880453
}

Received: 27 July 2020

Revised: 26 August 2020

Accepted: 2 September 2020

\begin{abstract}
Mathematics is a subject that must be mastered by every student because it relates to everyday life. However, many students consider mathematics to be a difficult and scary subject. Students only consider mathematics as a subject that includes numbers into the formula and the process of memorizing lessons. This results in low students' mathematical communication skills, especially in solving math tasks in the form of stories. This study aims to see the mathematical communication skills of students who are taught through the Team Assisted Individualized (TAI) type of cooperative learning model assisted by interactive media that is better than using scientific learning. The approach used in this research is quantitative. This research is a quasi experiment. The population of this study were all students of class VII and students of class VII 1 as the control class and class VII 3 as the experimental class. The samples were selected by purposive sampling. The research design used was the nonequivalent control group posttest-only design. Retrieval of data in the study using students' mathematical communication tests (posttest). Data collected from the results of the analysis test using SPSS 25 to find normality using the One-Sample Kolmogorov-Smirnov Test, and hypothesis testing using the Mann-Whitney U test. Regarding the research objectives, the results obtained from this study are students' mathematical communication skills. through cooperative learning type Team Assisted Individualized (TAI) assisted by interactive media gives an effect compared to students who get scientific learning. Based on the results of the Mann-Whitney U test, it is known that the Asymp value. Sig. (2-tailed), namely $0.001<$ a 0.05 .
\end{abstract}

Keywords: blended learning; face-to-face learning; motivation; learning achievement;

\section{Introduction}

Learning is an activity that takes place between teachers and students. Learning can be said to be successful if the learning can find good results as well as learning mathematics. The success of students in mathematics is influenced by teachers who must be able to plan and carry out mathematics learning well. Mathematics is a science that has an important role in the development of science and technology. In its development, mathematics has many things or insights that can be taken or learned in learning mathematics. Therefore, mathematics must be studied with the correct understanding, in learning mathematics there are several characteristics of mathematics learning that must be understood, in line with Soedadi's opinion (Lestari, 2019: 1) suggesting the characteristics of mathematics, namely having an abstract object study, based on agreement, having a mindset deductive, has a symbol that is empty of meaning, paying attention to the universe of speech, consistent in its system.

Concepts and principles are basic knowledge that students must have so that students can solve math problems properly. According to Great Dictionary of the Indonesian Language (KBBI) (Egawati and Saragih 2018: 3) principles are principles of truth which are the basic principles of thinking. But until now, many students find it difficult to learn mathematics. Difficulties related to principles, difficulties in using symbols, difficulties due to weak calculations, and difficulties in understanding the language of mathematics.

One of the goals of learning mathematics is to have skills and proficiency in learning mathematics. Skills and proficiency are the life skills that students must have, especially in daily life communication. These skills or skills are closely related, which both strengthen and need the other. Even if it is not stated explicitly, communication skills emerge and are needed in various skills, for example, to explain ideas on conceptual understanding, present formulations and problem-solving, or put forward reasoning arguments. As stated in the Ministry of Education and Culture, the objectives of learning mathematics in implementing the 2013 
Curriculum are: (1) Students are able to improve intellectual abilities, (2) Shaping students' abilities to solve problems systematically, (3) Obtaining high learning outcomes (4) Training students in communicating ideas, especially in writing works, (5) Developing student character.

The learning objectives according to the National of Council Teachers of Mathematics (NCTM) (Abda 2019: 2) are to develop mathematical abilities which include: problem-solving ability, reasoning ability, representation ability, ability to make connections (connection), the ability to communicate (communication) and the formation of positive attitudes toward mathematics. One of the goals of learning mathematics is to have students' mathematical communication skills. To achieve the goal of learning mathematics the teacher must be creative, the learning process is a process of communication between the teacher and students through verbal language as the main medium for delivering learning material. The learning process is very dependent on the teacher and learning resources.

Several previous studies, Subiyantari et al, (2019), Irfanto et al, (2019), Wahyuni et al, (2020) stated that the learning model greatly determines student success in learning, and can provide good learning outcomes. This is in line with Ichsan \& Rahmayanti's (2020) research that a good learning environment contributes to the development of students' thinking skills easily. In addition, Roisyah (2019) developed a learning model to increase creativity and the results needed by teachers, in order to increase creativity and reading and writing. Similar research by Hidayatul et al, (2020) and Pohan, (2019) states that the learning model has an impact on students' critical thinking skills in schools, and improves learning outcomes in language lessons. Not only the learning model, in research Sukariasih et al. (2019) stated that interactive multimedia also gives students interest in learning, besides that it makes students easy to understand it can also motivate. In line with Gartika et al, (2019) the development of interactive mathematics multimedia teaching materials can help students learn mathematics easily. Therefore, learning models and teaching materials also have an important role in supporting student learning success in every lesson in school.

However, in reality, not all learning materials can be presented directly. Because many students are still not aware of the importance of studying mathematics. They consider mathematics to be a difficult and frightening subject and mathematics is only a process of memorizing and entering numbers into formulas. So that it causes students to be lazy to learn mathematics which has an effect on the learning process not going well. As in the results of observations, researchers get information that there are still many students who do not understand the questions given, so that students find it difficult to write down ideas, and symbols into mathematical form. This causes students to lack communication skills in mathematics, especially in Social Arithmetic material. In everyday life, they still use the regional language (Aceh) and do not understand much Indonesian which has an impact on solving questions about the form of the story.

To create a quality learning process, teachers often find it difficult to provide learning material in schools which still shows shortcomings and limitations. Especially giving a concrete picture of the material presented, so that it results in low mathematical communication of students and unequal quality of results achieved by students. This kind of condition will continue to occur as long as the mathematics teacher still thinks that he is a learning resource for students and ignores learning media. One of the media that can be used is interactive media. Interactive media is media that is not linear, but students have choices according to the menu offered. In learning a topic of discussion students can choose which one to learn first. Thus, the characteristic of interactive media is the existence of a kind of controller called a graphical user interface (GUI), which centers on icons, buttons, scrolls, or others. Each GUI can be operated by students (users) to find the information that Sanjaya (2016: 225) wants.

One of the media that can be used is by using Microsoft PowerPoint. Because Microsoft PowerPoint can help in the learning process. The appearance is not boring so students are interested in following the lesson. In this PowerPoint, students can choose which one is needed for learning because it has very interesting communication. Researcher must admit that the media make a positive contribution to the learning process. Learning that uses the right media will provide optimal results for students' understanding of the material being studied. According to Kemp (Sundayana 2015: 3), the contribution of media in learning is that learning can be more interesting. This will be in line with the 2013 curriculum, namely the curriculum that prioritizes understanding, skills, and character education. Students are required to understand the material, be active in discussions and be polite and disciplined. According to Rumapea (2013: 27) says that the 2013 Curriculum forms students to make observations/observations, ask questions, and reason about the knowledge being taught. Students are given subjects with integrated themes to have knowledge about the environment, life, and strong personal foundations in social life and to have better creativity. In the 2013 curriculum, students are encouraged to be active in the learning process, one of the lessons that make students active is cooperative learning.

There are several types of cooperative learning models. One of them is the type of model that can provide students with mathematical communication skills, namely the Team Assisted Individualized (TAI) type of cooperative learning model. The TAI cooperative learning model is a learning model that combines 
cooperative learning with individual teaching according to Slavin (2010: 191). This means that this type of TAI learning model takes into account the characteristics of each individual and their social life. In the cooperative model type TAI, students are divided into several groups consisting of 4 to 6 students heterogeneously and then given individual assistance to students who need it.

To make students socialize well, it is necessary to design student-centered learning that can direct and construct knowledge so that students are used to and able to communicate their mathematical ideas or ideas. Strategies that can be designed are by applying relevant learning methods, models, or approaches. One of them is by applying the TAI learning model assisted by interactive media which will have an impact on students' mathematical communication skills. As in the results of Silalahi's research (2019: 27), it is concluded that the average increase in the mathematical communication skills of students who get learning using the TAI type cooperative learning model is higher than the increase in mathematical communication skills of students using conventional learning models. Based on the existing problems, researchers are interested in applying the Team Assisted Individualized (TAI) learning model to determine students' mathematical communication skills. Therefore, the researcher took the title "The Influence of Cooperative Learning Model Type Team Assisted Individualized of Interactive Media Assistance to Students' Mathematical Communication Ability."

\section{Methods}

The approach used in this research is quantitative. The quantitative approach is research where calculations use a lot of numbers starting from data collection, interpretation of the data, and the appearance of the results (Arikunto, 2014: 27). The type of research used in this research is quasi-experimental or quasiexperimental that uses two groups, namely the experimental group and the control group. The experimental class with the TAI learning model assisted by interactive media and the control class were given treatment with scientific learning. This study using a nonequivalent control group posttest-only design according to (Privitera and Delzell, 2019) which is described as follows:

Table 1. Research Design

\begin{tabular}{|ll|}
\hline $\mathrm{X}$ & $\mathrm{O}_{1}$ \\
& $\mathrm{O}_{2}$ \\
& \\
\hline
\end{tabular}

Description

$X$ : treatment

$\mathrm{O}_{1}$ : value of posttest for experiment class

$\mathrm{O}_{2}$ : value of posttest for control class

As for the population in this study were all class VII students of SMP N 6 Lhokseumawe. The sample is part or representative of the research Arikunto (2014: 174). In this study, the sample was taken with a sampling technique, namely nonprobability sampling, namely purposive sampling which aims to be carried out with certain considerations Sugiyono (2016: 85). According to Arikunto (2014: 177). This technique is done based on a specific goal. As for the sample in this study were students of class VII-3 at SMP N 6 Lhokseumawe. This research was conducted at SMP N 6 Lhokseumawe, Muara Satu District, North Aceh Regency, Aceh, Indonesia.

Table 2. Study Time

\begin{tabular}{|c|c|c|c|c|c|c|c|c|c|c|c|c|c|}
\hline \multirow{2}{*}{ No. } & \multirow{2}{*}{ Activities } & \multicolumn{12}{|c|}{ Months } \\
\hline & & 7 & 8 & 9 & 10 & 11 & 12 & 1 & 2 & 3 & 4 & 5 & 6 \\
\hline 1 & Observation Field & & & & & & & & & & & & \\
\hline 2 & Proposal Submission & & & & & & & & & & & & \\
\hline 3 & Proposal Seminar & & & & & & & & & & & & \\
\hline 4 & Proposal Revision & & & & & & & & & & & & \\
\hline 5 & Test Question Validation & & & & & & & & & & & & \\
\hline 6 & Making Learning Instruments & & & & & & & & & & & & \\
\hline 7 & Data Collect & & & & & & & & & & & & \\
\hline 8 & Data processing & & & & & & & & & & & & \\
\hline 9 & Thesis Preparation & & & & & & & & & & & & \\
\hline 10 & Thesis Defence & & & & & & & & & & & & \\
\hline
\end{tabular}

In this study, the test type instrument was the posttest of students' mathematical communication skills which consisted of 10 questions but used in this study only 4 questions that had been validated. The grid and alternative items for the answers to the communication skills test showed in Table 3. 
Table 3. Mathematical communication grids

\begin{tabular}{lc}
\multicolumn{1}{c}{ Aspects } & Questions \\
& Number \\
\hline Be able to explain mathematical completion procedures & 1 \\
\hline Be able to express everyday events in a mathematical model. & 2 \\
\hline Able to read with the understanding of a written mathematics presentation and formulate relevant questions & 3 \\
\hline Able to explain mathematical ideas, situations and relations orally and in writing & 4 \\
\hline
\end{tabular}

To facilitate scoring, it is necessary to have an alternative scoring that the researchers use as in the following table. The scoring guidelines can be seen in Table 4.

Table 4. Guidelines for Scoring Mathematical Communication Skills

\begin{tabular}{|c|c|c|}
\hline Rated aspects & Indicators & Scores \\
\hline \multirow{5}{*}{$\begin{array}{l}\text { Be able to express everyday events in a } \\
\text { mathematical model. }\end{array}$} & No answer at all & 0 \\
\hline & Not writing everyday events into a mathematical model at all & 1 \\
\hline & Writing at all the everyday events into a mathematical model is incorrect & 2 \\
\hline & Write down all the daily events into a mathematical model but not complete & 3 \\
\hline & $\begin{array}{l}\text { Write down all the daily events into a mathematical model correctly and } \\
\text { completely }\end{array}$ & 4 \\
\hline \multirow{5}{*}{$\begin{array}{l}\text { Explain mathematical ideas, situations } \\
\text { and relations. }\end{array}$} & No answer at all. & 0 \\
\hline & Do not put mathematical ideas into words at all. & 1 \\
\hline & Writing down math ideas with incorrect words. & 2 \\
\hline & Write down mathematical ideas in correct but incomplete words. & 3 \\
\hline & Write down mathematical ideas in words correctly and completely. & 4 \\
\hline \multirow{5}{*}{$\begin{array}{l}\text { Able to read with the understanding } \\
\text { of a written mathematics presentation } \\
\text { and compose relevant questions. }\end{array}$} & No answer at all. & 0 \\
\hline & Unable to compose question. & 1 \\
\hline & Write down mathematical ideas in a structured but incorrect way. & 2 \\
\hline & Write down mathematical ideas correctly but incompletely. & 3 \\
\hline & $\begin{array}{l}\text { Write down mathematical ideas in a structured manner correctly and } \\
\text { completely. }\end{array}$ & 4 \\
\hline \multirow{5}{*}{$\begin{array}{l}\text { Be able to explain mathematical } \\
\text { completion procedures }\end{array}$} & No answer at all. & 0 \\
\hline & Does not explain the settlement procedure at all. & 1 \\
\hline & Improperly explained the completion procedure. & 2 \\
\hline & Completing the completion procedure properly but incompletely. & 3 \\
\hline & Explain the completion procedure correctly and completely. & 4 \\
\hline
\end{tabular}

\section{Source: Modified from Utari Sumarmo (Teaching Materials: 4).}

Before this research was conducted, the instrument was tested to obtain validity, reliability, difficulty level, and distinguishing power of the instrument's difficulty level. As for obtaining accurate data, tests are used. Tests that meet good criteria, namely test validity, reliability, distinguishing power, and which have a minimum level of difficulty.

\section{Results and Discussion}

Results of the Instrument Test

Before the research was carried out, the instrument testing was carried out in class VIII-3 with 10 items given to 26 students on January 2, 2020. The test results of the instrument were to determine the validity and the items, the Item Reliability. The problem, level of difficulty, and distinguishing power of the question.

\section{Results of the Test the Validity of Question Items}

The instrument (test questions) that researchers used to test the experimental class and the control class. The purpose of this validity test is to be able to find out whether item items can measure what they want to measure so that they get accurate data and meet good criteria Fahrulissa (2018: 75). The process of calculating the validity of the communication skills test items using Microsoft Excel 2010 software and a complete calculator can be seen in the attachment.

Table 5. Validity of Question Items

\begin{tabular}{ccccc}
\hline Items & $\mathrm{r}_{\mathrm{xy}}$ & $\mathrm{t}_{\text {count }}$ & $\mathrm{t}_{\text {table }}$ & Interpretations \\
\hline 1 & 0,33 & 1,67 & 1,717 & T. Valid \\
2 & 0,46 & 2,45 & 1,717 & T. Valid \\
3 & 0,26 & 1,28 & 1,717 & T. Valid \\
4 & 0,55 & 3,13 & 1,717 & Significant/Valid \\
5 & 0,57 & 3,25 & 1,717 & Significant/Valid \\
6 & 0,47 & 2,51 & 1,717 & T. Valid \\
7 & 0,10 & 0,51 & 1,717 & T. Valid \\
8 & 0,52 & 2,88 & 1,717 & Significant/Valid \\
9 & 0,57 & 3,33 & 1,717 & Significant/Valid \\
10 & 0,40 & 2,05 & 1,717 & T. Valid \\
\hline
\end{tabular}


Based on the table 5 above, it can be seen that of the 10 questions that were tested for validity, only 4 questions were valid, namely questions number 4, 5, 8, 9 and 6 questions which were invalid, namely numbers $1,2,3,6,7$, and 10 . Therefore, the researcher only took 4 questions from the results of the validity test to make them into post-test questions in the study, namely questions number 4, 5, 8 and 9 .

\section{Test Item Reliability Test}

The process of calculating the reliability of the test items for communication skills using Microsoft Excel 2010 software and a complete calculator can be seen in the attachment. The result of the calculation is 0.81 , it can be concluded that the item has a high interpretation.

Test Item Discriminatory Power

The process of calculating the distinguishing power of communication skills test items using Microsoft Excel 2010 software and a complete calculator can be seen in the attachment.

Table 6. Distinguishing power

\begin{tabular}{cccc}
\hline Items & Dp & Interpretation & Descriptions \\
\hline 1 & 0,27 & Moderate & Problem fixed \\
2 & 0,47 & Very good & Problem accepted/good \\
3 & 0,20 & Moderate & Problem fixed \\
4 & 0,52 & Very good & Problem accepted/good \\
5 & 0,41 & Very good & Problem accepted/good \\
6 & $-0,18$ & Ugly & Problem is not repaired/ removed \\
7 & $-0,02$ & Ugly & Problem is not repaired/ removed \\
8 & 0,33 & Good & Problem accepted but needs to be fixed \\
9 & 0,37 & Good & Problem accepted but needs to be fixed \\
10 & 0,27 & Moderate & Problem fixed \\
\hline
\end{tabular}

Based on the calculation of the distinguishing power in the table above with 10 items, 3 items are corrected, 3 items are accepted/good, 2 items are corrected/removed because these questions have a bad distinguishing power, meaning that these questions cannot distinguish between students who high ability with low ability students so that the questions cannot be used in the instrument test and the questions are accepted but need to be corrected as much as 2 items.

Level of Difficulty

Test the level of difficulty to find out the level of difficulty of each item, whether it is easy, medium, or difficult. The process of calculating the level of difficulty of the communication skills test items using Microsoft Excel 2010 software and a complete calculator can be seen in the attachment.

Table 7. Level of Difficulty

\begin{tabular}{ccc}
\hline Items & Level of Difficulty & Descriptions \\
\hline 1 & 0,73 & Easy \\
\hline 2 & 0,63 & Moderate \\
\hline 3 & 0,66 & Moderate \\
\hline 4 & 0,69 & Moderate \\
\hline 5 & 0,66 & Moderate \\
\hline 6 & 0,58 & Moderate \\
\hline 7 & 0,44 & Moderate \\
\hline 8 & 0,70 & Easy \\
\hline 9 & 0,29 & Hard \\
\hline 10 & 0,54 & Moderate \\
\hline
\end{tabular}

The results of the test questions that have been carried out to students were 10 items obtained 2 easy items, 7 moderate questions, and 1 difficult item. The items carried out in this study are from easy to difficult. Because easy or difficult items do not distinguish high-ability students and low-ability students. The following conclusions from the results of the validity, reliability, level of difficulty and differentiation of students' mathematical communication skills tests are presented in the following table:

Table 8. Recapitulation of Test Results of Validity, Reliability, Distinguishing Power, and Level of Difficulty

\begin{tabular}{|c|c|c|c|c|c|}
\hline Items & Validity & Reliability & $\begin{array}{c}\text { Discriminatory } \\
\text { Power Level }\end{array}$ & $\begin{array}{c}\text { Exam's difficulty } \\
\text { level }\end{array}$ & Descriptions \\
\hline 1 & T. Valid & \multirow{10}{*}{ High } & 0,27 & Moderate & Revised question \\
\hline 2 & T. Valid & & 0,47 & Very good & Accepted \\
\hline 3 & T. Valid & & 0,20 & Moderate & Revised question \\
\hline 4 & Significant / Valid & & 0,52 & Very good & Accepted \\
\hline 5 & Significant / Valid & & 0,41 & Very good & Accepted \\
\hline 6 & T. Valid & & $-0,18$ & Not good & Deleted \\
\hline 7 & T. Valid & & $-0,02$ & Not good & Deleted \\
\hline 8 & Significant / Valid & & 0,33 & Good & Accepted, if revised \\
\hline 9 & Significant / Valid & & 0,37 & Good & Accepted, if revised \\
\hline 10 & T. Valid & & 0,27 & Moderate & Revised question \\
\hline
\end{tabular}


Based on the results of the analysis of the validity, reliability, level of difficulty and differentiation of students' mathematical connection ability tests that have been tested, it is feasible to be used as a test instrument. From the test results, 4 (four) questions will be taken, namely questions number 4,5,8, and 9 . Furthermore, these questions will be used as pre-test and posttest questions in this study. In this study, the test was used to determine students' mathematical communication skills in writing which would be carried out once, namely the Final Test (Posttest). using the TAI type learning model on students' mathematical communication skills. The posttest consists of 3 description questions that have been validated by experts. In this quantitative research, data on students' mathematical communication skills were obtained through the posttest results. The data obtained were then performed descriptive statistical calculations by making a frequency distribution. After that, the analysis prerequisite test was carried out with statistical calculations. The data processed from the experimental class and control class. Furthermore, the data were tested using the $t$-test at the significant level $a=0.05$. After the overall data is collected, the data is processed using statistical analysis t-test.

\section{Results of the Instrument Test}

This research was conducted to determine the effect of TAI-type cooperative learning model assisted by interactive media on students' mathematical communication skills. The influence of students' mathematical communication skills was obtained from the posttest score. While the posttest scores were obtained from each control and experimental class.

Table 9. Descriptive Statistics

\begin{tabular}{|c|c|c|c|c|c|c|c|c|c|c|}
\hline \multirow{2}{*}{ Values } & \multicolumn{5}{|c|}{ Experiment Class } & \multicolumn{5}{|c|}{ Control Class } \\
\hline & $\mathrm{N}$ & $X_{\min }$ & $\mathrm{X}_{\max }$ & $\overline{\mathrm{x}}$ & $\mathrm{s}$ & $\mathrm{N}$ & $X_{\min }$ & $\mathrm{X}_{\max }$ & $\overline{\mathrm{x}}$ & $\mathrm{s}$ \\
\hline Posttest & 32 & 2 & 4 & 3,19 & ,931 & 32 & 0 & 4 & 2,06 & 1,343 \\
\hline \multicolumn{11}{|c|}{ Maximum Score $=14$} \\
\hline
\end{tabular}

The table 9 showed that the minimum post-test score of students' mathematical communication skills in the experimental class is 2 , while in the control class it is 0 , while the maximum score in the experimental class and control class is the same, namely 4.From the average value it can also be seen that the experimental class has more value. 3.19 height compared to the control class that is 2.06. Likewise, the standard deviation in the experimental class was 0.931 while in the control class it was 1.343.

\section{Normality test}

The normality test in this study used the Kolmogorov Smirnov normality test on the post-test data. The complete calculation results can be seen in the attachment. The following is the normality test result data showed in table 10.

Table 10. Normality Test

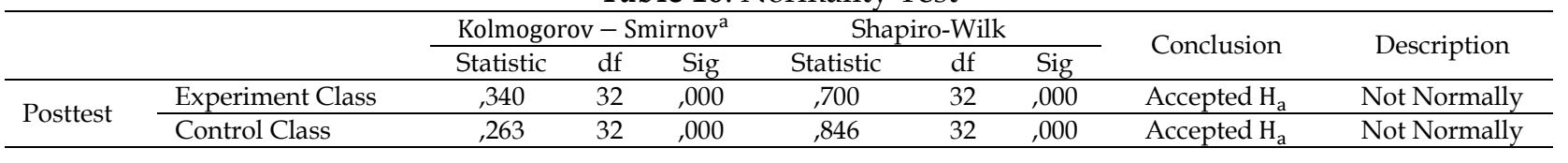

Based on the results of the normality test, it is known that the significance value is $0.000<0.05$. Based on the provisions $\mathrm{H}_{0}$ is rejected and Ha disaccepted if the significant value is $>0.05$. So it can be concluded that the post-test scores of students' mathematical communication skills are not normally distributed.

\section{Hypothesis testing}

After the pre-test data analysis requirements are not met, the data analysis cannot be continued using the $t$ test, but with Mann-Whitney Non Parametric. The test was carried out with SPSS 25 software and the details can be seen in the attachment. The following is a summary of the results of the Mann-Whitney Non Parametric test, as follows:

Table 11. Non-Parametric Test

\begin{tabular}{lccc}
\hline Statistik & Value & Description & Conclusion \\
\hline Mann Whitney U & 275,500 & & H \\
\cline { 1 - 2 } Asymp. Sig (2 tailed) &, 001 & $H_{0}$ Rejected & $H_{1}$ Accepted \\
\hline
\end{tabular}

Based on the statistical test output, it is known that the Asymp. Sig. (2-tailed) of $0.001<0.05$, it can be concluded that the hypothesis is accepted. Thus it can be said that there are differences in the Experiment class and the Control class. Because there are significant differences, it can be said that there is an influence of the TAI type of interactive media assisted learning model on students' mathematical communication skills. The testing is based on the following hypothesis:

H0: $\mu_{1}=\mu_{2}$ : Through the cooperative learning model type TAI assisted by interactive media in the student learning process has no effect on students' mathematical communication skills.

Ha: $\mu_{1} \neq \mu_{2}$ : Through the cooperative learning model type TAI assisted by interactive media in the student learning process it affects students' mathematical communication skills. 
The decision making criteria for testing the data are as follows:

1). If the significance value $=0.05$ then $\mathrm{H}_{0}$ is rejected

2). If the significance value $=0.05$ then Ha is accepted

\section{Conclusion}

Based on the results of the analysis and discussion obtained the researcher concluded that by applying the Team Assisted Individualized (TAI) type of cooperative learning model assisted by interactive media had an influence on the results of students' mathematical communication skills compared to the control group that used scientific learning in lessons. mathematics class VII SMP Negeri 6 Lhokseumawe. Based on the statistical test output, it is known that the Asymp. Sig. (2-tailed) of $0.001<0.05$, it can be concluded that the hypothesis is accepted. Thus it can be said that there are differences in the Experiment class and the Control class. Because there are significant differences, it can be said that there is an influence of the TAI type of interactive media assisted learning model on students' mathematical communication skills.

\section{Recommendation}

Suggestions in this study are as follows: (1) For schools, to improve learning outcomes in mathematics and other subjects, the school should provide more diverse facilities, so that children's abilities in learning, (2) For teachers, cooperative learning models other than TAI can used as an alternative in learning mathematics on social arithmetic material to improve students' mathematical communication, (3) For students in the learning process they can learn in groups, to make it more fun and eager to improve their learning outcomes.

\section{Acknowledgement}

The authors would like to thanks to the people who have been instrumental in their assistance and the successful completion of this study.

\section{Author's Contributions}

All authors discussed the results and contributed to from the start to final manuscript.

\section{Conflict of Interest}

The authors declare that they have no competing interests.

\section{References}

Abda, M, I. (2019). Penerapan Pendekatan Omatic, Auditory, Visual dan Intelectual (SAVI) Untuk Meningkatkan Kemampuan Komunikasi Matematis Siswa Di SMK Negeri 1 Nisam.

Ansari, I. B. (2016). Komunikasi Matematik Strategi Berfikir dan Manajemen Belajar Konsep dan Aplikasi. Banda Aceh: Penerbit Pena.

Arikunto, S. (2014). Prosedur Penelitian suatu Pendekatan Praktik. Jakarta: Rineka Cipta.

Egawati dan Saragih. (2018). Kesulitan Belajar Matematika Berkaitan dengan Konsep pada Topik Aljabar: Studi Kasus pada Siswa Kelas VII Sekolah ABC Lampung.Universitas Pelita Harapan.

Gartika, E., Rahayu, W., \& Utomo, E. (2019). Development of Interactive Mathematics Multimedia Teaching Materials for Building Space in Class V Primary Schools. International Journal for Educational and Vocational Studies, 1(5), 467-472.

Hidayatul, A., Nasution, N., \& Nugroho, P. H. (2020). The Impact of Discovery Learning Models on The Critical Thinking Ability of Students at Middle-School. International Journal for Educational and Vocational Studies, 2(4).

Ichsan, I. Z., \& Rahmayanti, H. (2020). ITA: Innovation of Science and Environmental Learning Model in 21st Century based on HOTS. International Journal for Educational and Vocational Studies, 2(4).

Irfanto, W. Y., Mustaji, M., \& Jacky, M. (2019). The Effect of Cooperative Learning Model Type Two Stay Two Stray and Learning Style on Social Sciences Learning Outcomes of Grade IV Elementary School Students. International Journal for Educational and Vocational Studies, 1(3), 212-216.

Kemdikbud. (2013). Permendikbud no. 65 Tentang Standar Proses Pendidikan Dasar dan Menegah. Jakarta: Kementrian Pendidikan dan Kebudayaan.

Lestari Dkk. (2019). Analisis Kesulitan Belajar Siswa SMP Kelas VII Dalam Menyelesaikan Soal Matematika Di Tinjau Dari Kemampuan Komunikasi Matematis. Jurnal Ilmu Pendidikan. Vol 01, No. 02, Februari hal $440-444$. 
Ningsih, W. K., Riyanto, Y., \& Suyanto, T. (2019). The Development of Pop Up 3D General Map Using Discovery Learning Models to Improve Creativity and Learning Outcomes of Social Studies Grade V Elementary School. International Journal for Educational and Vocational Studies, 1(2), 86-91.

Pohan, J. E. (2019). The Development of Inquiry Learning Model on Indonesian Language Lessons. International Journal for Educational and Vocational Studies, 1(4), 335-338.

Privitera, G.J dan Delzell, L.A. (2019). Research Methods For Education Sage Publications. California.

Rumapea, M. 2013. Kurikulum 2013 Yang Berkarakter. Jupiis, (Online), Vol 5, No. 2, (http://jurnal.unimed.ac.id/2012/index.php/jupiis/article/view/1112/882.

Roisyah, K., Mintowati, M., \& Roni, R. (2020). The Development of AKK Learning Model (Active, Creative, Communicative) through Cartoon Media for Reading Comprehension of Mandarin Language Learning For the Tenth Graders. International Journal for Educational and Vocational Studies, 2(5).

Sanjaya, W. (2016). Media Komunikasi Pembelajaran. Jakarta. Kharisma Putra Utama

Silalahi N,M. (2019). Pengaruh Model Pembelajaran Kooperatif Tipe Team Assisted Individualization (TAI) Terhadap Kemampuan Komunikasi Matematis Siswa SMP. Cartiesius: Jurnal Pendidikan Matematika p-ISSN 26232251 Juni 2019 Vol. 2, No. 1, Hal 16. (NM Silalahi - CARTESIUS: Jurnal Pendidikan Matematika, 2019 ejournal.ust.ac.id). Diakses pada 10 Oktober 2019.

Slavin R,E. (2010). Cooperative Learning Teori, Riest, dan Praktik. Bandung. Nusa Media.

Subiyantari, A. R., Muslim, S., \& Rahmadyanti, E. (2019). Effectiveness of Jigsaw Cooperative Learning Models In Lessons of the Basics of Building Construction on Students Learning'Outcomes Viewed From Critical Thinking Skills. International Journal for Educational and Vocational Studies, 1(7), 691-696.

Sudayana. H,R. (2015). Media Dan Alat Peraga Dalam Pembelajaran Matematika. Bandung. Alfabeta.

Sugiyono. (2016). Metode Penelitian Pendidikan, Pendekatan Kuantitatif, Kuliatatif, dan R\&D. Bandung. Alfabeta.

Sugiyono. (2017). Metode Penelitian Pendidikan, Pendekatan Kuantitatif, Kuliatatif, dan R\&D. Bandung. Alfabeta.

Sukariasih, L., Erniwati, E., \& Salim, A. (2019). Development of interactive multimedia on science learning based adobe flash CS6. International Journal for Educational and Vocational Studies, 1(4), 322-329.

Sukino dan Simangunsong. (2006). Matematika untuk SMP Kelas VII KTSP 2006. Jakarta. Erlangga.

Sumarmo, U. Tanpa tahun. "Pedoman Pemberian Skor pada Beragam Tes Kemampuan Matematik". Jurnal Bahan Ajar diakses pada 16 oktober 2019.

Triana, N. (2019). Komparasi Model Pembelajaran Kooperatif Tipe Jigsaw dan Kooperatif Tipe Team Assisted Invidualization (TAI) Terhadap Pemahaman Konsep Matematis Siswa Kelas VII SMP Negeri 7 Palopo. Universitas Cokroaminoto Palopo.

Wahyuni, D., Samani, M., Wiyanto, T., \& Rijanto, T. (2020). Influences of Problem-Based Learning Models on Class XI Students Learning Outcomes in Subject of Light Vehicle Engine Maintenance at KAL-1 Vocational School Surabaya. International Journal for Educational and Vocational Studies, 2(5).

Wati. (2015). Ragam Media Pembelajaran, Visual-Audio Visual-Komputer-Power Point-Internet-Interactive video. 